Original Paper UDC 141.2:316.323.64

doi: $10.21464 / \mathrm{sp} 31101$

Received January $1^{\text {st }}, 2015$

\begin{abstract}
Alpar Lošonc
University of Novi Sad, Faculty of Technical Sciences, Trg Dositeja Obradovića 6, RS-21000 Novi Sad corna@eunet.rs
\end{abstract}

\title{
Why Don't We Live in the World Anymore?
}

\begin{abstract}
Starting with the crisis related to the embeddedness in the world in the late capitalism, this paper presents representative replicas in relation to this crisis-based constellation. It emphasizes three answers to the question of why do not we live in the world and why we are confronted with the term non-world. Jean-Luc Nancy elaborates a sophisticated and highly speculative philosophy dealing with the signification of the world. He pays special attention to the ending of the world by globalization processes. Developing a militant philosophy related to the capitalo-parliamentarism, Alain Badiou emphasizes the gap between the transcendental aspect of the world and the late capitalist conditions. Franck Fischbach is concerned with the articulation of our participation in the world by dispossession and leads us to the meaning of the privatized world. From the perspective of the meaning of the world, he significance of the analysis of the late capitalist society reproduction is pointed out. The author of the paper offers an argumentation that is based on the re-articulation of the notion of katechon in order to "save the world". Recalling the implications of real abstraction as the reality principle in capitalism, the paper provides a critical hermeneutics of real abstractions.
\end{abstract}

\section{Keywords}

world, crisis, capitalism, real abstraction, social determinations, katechon

If we ask the question whether or not we live in a world, listening to philosophical discourses in the last two centuries, the answer would be "no" without much hesitation. It should be noted that the above-mentioned period has brought to existence a tendency in philosophy which offers argumentation in favour of the fact that we do not live in the world. Has not phenomenology, or the philosophy that follows Heidegger and talks emphatically about the world and its non-object horizons, the transcendental category of "completeness", the world as a totality, ${ }^{1}$ or as an absolutely unavailable moment, always encountered critical processes? Has not self-reflection, so typical for modern philosophers, drawn into its whirl a crisis as a medium for self-understanding? In addition, we could say that the contemporary discourse about crisis always immanently incorporates the reflection about crisis. In this sense, Kierkegaard's statement on the imposed fact about birth ("How did I come into the world?") is just a symptom of the gnostic moments already present in the $18^{\text {th }}$ and $19^{\text {th }}$ century, ${ }^{2}$ and which predicted the epochal (crisis related) experience of alienation/strangeness.

Jan Patočka, Le monde naturel comme problème philosophique, Nijhoff, La Haye 1976, p. 5.
2

On gnostic aspects cf. Hans Jonas, The Gnostic Religion. The Message of the Alien God \& the Beginnings of Christianity, Beacon Press, 
Let us illustrate this relation between a crisis and a world experience with two contemporary examples. The starting point is the already mentioned phenomenology in which framework we find Maurice Merleau-Ponty, the philosopher who describes the baroque world as abundant in implications. His philosophy affirms the unbreakable co-presence of human beings and the world, that is, a strong syncretism. The moment of embeddedness is just not enough for a human being; Merleau-Ponty claims that we are "from the world". ${ }^{3}$ The concept of 'being-in-the-world' will surely always bring us back to the French philosopher who sees the world separately from the totality of things or causal relationships. On the other hand, we find a representative of modern acosmism among the phenomenologists, namely Michel Henry, who attacks all the contemplations that focus on the world. Thus, he also criticizes Heidegger for remaining inside the boundaries of the world philosophy. He shares the underlying motive (acosmism) with Spinoza, but the direction of his philosophy is different. Henry sees the dichotomy between life, which is connected with the primary self, and the world, ${ }^{4}$ that is, he presents the duality between the immediate subjective reality and the world. On the one hand, there is an individual phenomenological life, affectivity focused on the "living present", an experience of suffering and despair, while on the other hand, there is a world whose light shines on the mechanisms of mediation.

Nothing expresses this orientation as pregnantly as Henry's monography on Marx: phenomenological life (as a priori assumption about history) opposes the "history of the world" and the dialectical concept of history. ${ }^{5}$ Henry pleads for the consideration of the a priori conditions of history which are inherent in the factual flow of history, but those very conditions oppose the "ontological and ontic experience of the world". In this constellation, an individual phenomenological experience is characterized by a radical principle of non-relation. Such phenomenological affectivity is the key instance in relation to the world which is determined by objective dialectic mediation. Philosophy of the world is criticized for its illusory idea that life can be viewed in the context of the world - life cannot even be presented in the world which is promoted as the topos that enables the discovery of life. Life of originary ipseitas should be isolated from the world and it should not be attributed with any world-related "meanings". Philosophy which sees the category of life independently from the world defines Marx's proletariat from the aspect of phenomenological affectivity. Only then, when it is opposed to the world, affectively defined proletariat can be positioned in the context of the "production of life". Only affectivity can establish the dynamics between the history and a path of a world-historical individual because

"... if a human being is a being of the world intelligible in the truth of the world, then we must come to terms with him: this human being is not an Ipseity (...). And a human being who is not an Individual and who is not a Self is not a man. The human being of the world is merely an optical illusion. "Man'does not exist." 6

This criticism of immanent life can be understood only if we bear in mind the fact that Henry writes about epochal crisis. He thematises the world provocatively, from the aspect of the omnipresent crisis. The world is never discussed without mentioning the crisis. The world is not an intersection of the abundant diversifications which can be articulated phenomenologically, but a bunch of mediations and representations. Henry does not hesitate to use the term 'barbarism'; ${ }^{7}$ the dramatic depiction of the present is marked with critical moments. Barbarism is the negation of life. Art, while still deserving its name, is a constant protest against the self-negation of life. Henry mocks 
the venal artists lost in their presentation of the world, who also support ocularcentric orientation. In the book Du communisme au capitalisme. Théorie d'une catastrophe, which can be categorized as one of the rare ventures that philosophically treat the subject of transition from "communism to capitalism" ${ }^{8}$ Henry mentions fascism and recognizes the possibility of its growth in real-socialism and post-socialist capitalism.

While reading Henry's work, we cannot ask the question - why don't we live in the word anymore? What we see as a problem, Henry sees as an assumption. Henry's philosophy is on the other side of the reflection about the world; he sees the world as a form of rooted crisis. At the same time, his philosophy, which tends to reformulate everything, follows the crisis in the world.

We shall now turn to another thinker, Odo Marquard, who sees himself as a "sceptical conservative", and who is important for our comprehension of the relation between the world and crisis. As a conservative, he should be sensitive to the various descriptions of the frantic socio-economic dynamics in the continuously accelerating world. He is not referring to the famous $19^{\text {th }}$ century crisis theoretician Jacob Burckhardt, ${ }^{9}$ who tackled the problem of acceleration long before current discussions, including the implications with respect to a "world-historical" individual. Historical crises are accelerated processes leading us to the conclusion that the modern world is identified with the modalities of acceleration. ${ }^{10}$ The pace of change continuously increases and the obsolescence of the phenomena that entered the world as a novelty is also speeding up: it is the modern panta rhei. Marquard sees the modern world in the context of a collective singularity, that is, as a universal history which is nothing more than an attempt to deal with the world as a topos of speed. In the modernity, human beings obey the speed of the world and create a universal history in order to cope with that speed.

A "sceptical conservative" aims at saving the world. The tendency of conservatism is always the conservation of the world - the indication which used to be mentioned quite often and which controversially deforms famous Marx's

Boston 2001, pp. 320-341. For a perspective on crisis in the world cf. Marion Bernard, "Le monde comme problème philosophique", Les Étudesphilosophiques 98(3/2011),pp.351-373. doi: https://doi.org/10.3917/leph.113.0351.

3

On the evidence of perception (Merleau-Ponty), and experience of the world (Patočka) cf. Émilie Tardivel, "La liberté comme expérience du monde", Philosophie 118 (2/2013), pp. 67-77. doi: https://doi.org/10.3917/phi10.118.0067.

4

Michel Henry, Incarnation, Seuil, Paris 2000, pp. 135; Peter Hallward, "The One or the Other. French Philosophy Today", Angelaki 8 (2/2003), pp. 1-32. doi: https://doi.org/10.10 80/0969725032000162549.

5

Michel Henry, Marx (Vol. I, Une philosophie de la réalité), Gallimard, Paris 1976, p. 186.
6

Michel Henry, I Am the Truth. Toward a Philosophy of Christianity, Stanford University Press, Stanford 2003, p. 124.

7

Michel Henry, La Barbarie, Grasset, Paris 1988, p. 161.

8

Cf. Michel Henry, Du communisme au capitalisme. Théorie d'une catastrophe, Odile Jacob, Paris 1990.

9

Jacob Burckhardt, Weltgeschichtliche Betrachtungen (Jacob Burckhardts Gesammelte Werke, Vol. 4), Schwabe \& Co Verlag, Basel - Stuttgart 1970, p. 193; Odo Marquard, "Universalgeschichte und Multiversalgeschichte", in Odo Marquard, Apologie des Zufälligen, Philipp Reclam, Stuttgart 1986, pp. 54-75.

10

Reinhart Koselleck, Vergangene Zukunft: Zur Semantik geschichtlicher Zeiten, Suhrkamp, Frankfurt am Main 1979. 
thesis by stating that philosophers of history changed the world in different ways, yet their goal was to defend it. ${ }^{11}$ Therefore, our epoch will be viewed in the light of conservation - the rejection of eschatology (which negates the world) has conservative implications. Humble conservatism defends the world against gnostic flurry that calls for a god outside of this world for salvation - a reference to late Gnosticism as the destructor of the world is a frequent indication of controversy in regard to modern philosophers. ${ }^{12}$ Marquard announces discordance with every program which ends in the absolution of human beings. He wants to save the world by placing a human being in a contingent world, in a place where human beings are determined by narration and contingencies. Marquard does not aim at tribunalization, which is judging the world in the name of criticism. Tribunalization closes the door to the world in order to judge the world for the final time. The final judgment is made with our search for the meaning of our experiences, as the world, aiming at the final truth, exposes itself to the crisis. There is a discussion about the "rapid alienation from the world", which implies the "dispersion of experience". ${ }^{13}$ The "dispersion of experience" refers to the fact that the optics of youth, presenting the world contingencies, expose themselves to the fear of the disorder of dispersed contingencies. Ambitions aimed at overcoming the contingencies culminated during the world crisis.

The philosophical reflections of Henry and Marquard use crisis to shed light on the world configuration: the first one transcends the world framework based on subjectivity, which cannot merge with the objectivity of the world, and the second one makes diagnosis regarding the crisis in the context of a necessity to defend the contingent horizons of the world, implying that all reflections aiming at something absolute will sooner or later end up in the negation of the world. The first one, employing a metahistorical dimension, that is, the moment of immediate subjectivity, refutes the philosophies of the world and the second one perceives antinomy of the contemporary constellation, together with the philosophy of the world and the affirmation of truth, imperils the world, but is still considered as the affirmation of the world.

\section{Crisis and the world, but from the perspective of socialization}

In order to answer the question why do not we live in the world anymore, we first need to make one decision. Here, also, we take the same path as Henry, but differently from the French philosopher. Whenever Henry assails the dialectics which focuses on the world objectivity, he also criticizes the hypostasis of society as the main category. ${ }^{14}$ Since we have already mentioned his monograph about Marx, we should continue with the corresponding indications as Henry was always particularly interested in Marx's reflections, which could be interpreted as the affirmation of individual phenomenological life. That way, the implications such as "society as the reification of human substance", or "society as a single subject", and "fiction on the society as individual" can be found in the criticism. Thus, reading Marx as if he is a reality thinker, and that his thesis is not based on objectivity but phenomenological life, resolves Marx from the world aspect. ${ }^{15}$

It could be said that "society" appears as a perspective which leads to a new world. Criticism directed at a non-authentic world necessarily refers to a comprehension of society. It means that the interpretation of the world must include categories of society, and the processes ("mondialisation") that relate to the world ("being-in-the-world") always have "inter-social" significations. If 
we wish to discover whether there is a crisis in the interpretation of the world, we must include the articulation of social categories. The demarcation line cannot be drawn between the "world" and "reality", nor can the "world", at least when it is considered to be immanent, be spatially situated "behind" the society as a background complex of various categories. ${ }^{16}$ This kind of reasoning can lead us to an idea according to which the society is only imaginary and the world is the essence. However, we must not forget about the $a$ priori of the world with respect to society as an inevitable determining constellation. The analysis of the crisis that has hit the world must be based on social dynamics.

When Marquard discusses speed as an aspect of the last century, he fully recognizes the inevitable tendency, but with a lack of specific social categories he cannot reach the term "creative destruction" which is a determinant of the society that is defined by the dynamic of capital. Indeed, speed is the expression of structural social tendencies. Acceleration presents the temporal structures of capitalism in the sense that the negation behind "decomposition" becomes a positive entity. When Marquard relates the continual acceleration and alienation of the world he again recognizes the unavoidable aspect of our epoch, but he fails to see that continual acceleration is a paradox which leads to demobilization regarding the transcendence of society. Marquard disapproved the idea of the final truth being in a place forgotten by the God, yet we have another problem - the problem of transcendence in immanence. The general acceleration in the form of the socially established regimes of temporality results in rigidity regarding the changes of the status quo.

Why don't we try to understand Henry, the divider of "reality" into life and "corrupted" world, on the basis of "to understand the author better than the author himself" principle, that is, as a criticism of a fake world hiding interwoven determinations with a mark of "social"? Why not accept criticism about the world, which can be viewed in the manner of young Hegel, as "positivity"? Finally, if here we raise the unavoidable question of the divergence of "mondialisation" and "world", then aren't processes such as the worldwide homogenization of standards exactly the expression of "inter-social" tendencies? Aren't the discourses which thematise the "system-world"17 and contain numerous critical implications about perpetuating structural violence relevant for understanding the world? It is needless to prove that the triumphal unification of the world by means of capital can be understood only on the basis of

11

Odo Marquard, Schwierigkeiten mit der Geschichtsphilosophie, Suhrkamp, Frankfurt am Main 1982, p. 13.

12

Eric Voegelin, Wissenschaft, Politik und Gnosis, München, Kösel 1959. Taubes implies this in regard to Marx, whom he sees as the final figure of European eschatology and a thinker who rejects the world. Jacob Taubes, Occidental Eschatology, Stanford University Press, Stanford 2009, p. 171.

13

This evokes Walter Benjamin's reflections regarding the consequences of World War I.

14

M. Henry, Marx, pp. 162-223.
15

Marx does not have a positivistic concept of 'society'. For a different understanding of individual life cf. Luca Basso, Marx and Singularity. From the Early Writings to the Grundrisse, Brill, Leiden 2012.

16

Luc Boltanski, De la critique. Précis de sociologie de l'émancipation, Gallimard, Paris 2007 , p. 94. Boltanski reduces "reality" to static relationships and implies that the world is "immanent" without any "transcendence".

17

It is meant as the theory of world system. Cf. Jacques Bidet, "Le marxisme face à l'histoire globale", Actuel Marx 53 (1/2013), pp. 106120. doi: https://doi.org/10.3917/amx.053.0106. 
the analysis of social determinations. We are the relationship with the world, but always through a structured social constellation.

From this viewpoint, the reflection that involves the philosophical analysis of society ${ }^{18}$ is more than welcome, and it is relevant regarding the articulation of the world as generally concrete. We do not think about 'society' as something given but about the society which is determined by the logic of self-valuating capital, and this presumes fields furrowed with differences and the elements of power configuration. We are discussing the society which is torn by contradictions and which contradicts itself as well. Asking critically about the world which was created by history means searching between a true and a non-true structure, propagating the world as a place where truth, which predetermined for itself something that is non-true, can still be experienced. It is a society that is constantly being created because sociality is always mediated; it is created in the processes of mediation through the spheres of production, distribution, exchange, and consumption, by integrating and involving objects and the subjective capacities of human beings into the abstract commercial world where differentiation is realized on the basis of quantitative differences. Hence various discussions about the perception of objects ${ }^{19}$ in the modern world and the differentiated positions ${ }^{20}$ in the world must be filtered through the categories of this kind of sociality. The following question should be asked: what kind of world do we have in capitalism in which, according to the famous statement of Capital, wealth is "like" a "huge collection of commodities"? Not everything is a commodity or a prey of commodification, but everything appears in a certain form. ${ }^{21}$ Thus, the world (of commodities) is revealed in a certain modality.

Sociality considered here cannot be understood without bearing in mind the domination of "real abstraction". ${ }^{22}$ When we discuss the world from the perspective of history, we should be aware of the fact that the capitalist sociality cannot be understood without referring to the totalization dynamic of "real abstraction". This attribute indicates that this is not a mental structure as much as it is "real". It is operating social processes which condense different forms of "abstraction" - an abstractive balance. The question of the genesis of the historical world imposes the question about the history of "real" abstractions. From this viewpoint, the interpretation of real abstractions explains abstraction as a capitalistic principle of reality, the foundation of social "reality" as a "synthetic principle" which collects particularities into the articulated whole. ${ }^{23}$ Real abstraction acts as a "synthetic principle", meaning that sociality is included in toto, instead of just some of its categories being included.

The expression "society metes out measure for measure" 24 indicates the domination of abstraction which affects the experience of the world. Hence the formulation "socialized world". Thus, "real abstraction" delivers a measure for perception in the world. This throws light on the dynamic of temporality and spatiality, "the annihilation of space by time" (Marx), the differentiated forms of re-spatialisation, the various forms of simultaneity within the hierarchical regimes of temporality, synchronic and diachronic sequences, the forced synchronization in the name of the world market, "temporalization of space", ${ }^{25}$ separating acts in space, and the imposing of "nomos in space". ${ }^{26}$ This explains the regimes of adoption: an image of socially mediated crossing between time and space for the purpose of the realization of real abstraction reveals itself. Here we have a critical lamentation on space, where distance is being reduced and the concept of power-essence is created everywhere, ${ }^{27}$ and where the measure between adjacency and distance is lost, where every point 
in space is near, but spatial disorientation is created. Temporality and spatiality are used to measure the abstractions which spread diffusely throughout society, while abstractions introduce the standards through which disciplines and norms are realized.

Nothing should be added about "nature". ${ }^{28}$ Nature is observed as a set of the dynamics of real abstractions. This implies that we are moving away from the abstraction which, by following the subject-object logic, presents the metaphysical opposition between the human being and nature. Instead of the "Anthropocene" logic, which involves the assumed external influence of the "man" on nature, here we prefer "Capitalocene", i.e. a "world-ecology" which summarizes the dialectic unity of the breakthrough of capital and the "co-production of nature". ${ }^{29}$ Here, it is not only the society/nature duality that is deconstructed, but we also get an insight into the mentioned co-presence, but always in the context of the domination of real abstractions.

18

Franck Fischbach, Manifeste pour une philosophie sociale, La Découverte, Paris 2009.

19

Timothy Morton, Realist Magic: Objects, Ontology, Causality, Open Humanity Press, Ann Arbor 2013.

20

Jim Holt, Why Does the World Exist? An Existentialist Detective Story, Liveright Companion, New York 2012.

21

On erscheint cf. Massimiliano Tomba, Marx's Temporalities, Brill, Leiden 2012, p. 99.

22

This can be found in Simmel, but it explains Marx's approach: Georg Simmel, Philosophie des Geldes, Suhrkamp, Frankfurt am Main 1989, p. 57. On the differences between Marx's, Hegel's, and Feuerbach's understanding of abstractions cf. Gérard Bensussan, "Abstrait/concret", in: Georges Labica, Gérard Bensussan (eds.), Dictionnaire critique du marxisme, PUF, Paris 1999, pp. 4-5; Moishe Postone, Time, Labor, and Social Domination, Cambridge University Press, Cambridge 1993.

23

On the subject cf. Alberto Toscano, "The Open Secret of Real Abstraction", Rethinking Marxism 20 (2/2008), pp. 273-287. doi: https://doi.org/10.1080/08935690801917304. For a different account cf. Paolo Virno, "The Two Masks of Materialism", Pli: The Warwick Journal of Philosophy 12 (2001), pp. 167-173. Here, it is not a discussion about whether the domination of real abstraction can be treated in an epistemological or ontological key. Besides, the fact that abstraction is an operable principle in capitalism gives capitalism some philosophical dimensions. Capitalism is determined philosophically; its mechanisms are genuine philosophical prin- ciples. "Capital" is also a notion, and not just mere, simple power. It is not the "bourgeoisie" that rules, it is the "notion".

24

Theodor W. Adorno, Negative Dialectics, Routledge, New York 1973, p. 283.

25

Cf. M. Tomba, Marx's Temporalities.

26

This indication is based on Husserl and Carl Schmitt; cf. Frederic Jameson, "Notes on the Nomos", The South Atlantic Quarterly 104 (2/2005), pp. 199-204. doi: https://doi. org/10.1215/00382876-104-2-199. Fredric Jameson, Representing Capital: A Reading of Volume One, Verso, London 2014, p. 109.

27

On Heidegger's descriptions cf. Franck Fischbach, La privation de monde, Librarie Philosophique - Vrin, Paris 2011, p. 18.

28

On "nature" as a problematized category cf. Timothy Morton, Ecology without Nature, Harvard University Press, Cambridge (MA) 2007.

29

"Anthropocene" narration presents the "human being" who achieves power over nature; for criticism of this point cf. Andreas Malm, Alf Hornborg, "The Geology of Mankind? A Critique of the Anthropocene Narrative", The Anthropocene Review 1 (1/2014), pp. 62-69. doi: https://doi.org/10.1177/20530196135162 91. For the notion of "Capitalocene" cf. Jason Moore, "'This lofty mountain of silver could conquer the whole world'. Potosí and the political ecology of underdevelopment, 1545-1800", Journal of Philosophical Economics 4 (1/2010), pp. 58-103. Here, "nature" is a matrix which operates through human body. 
Thus, capitalist sociality and the historical specificity of corresponding abstractions is viewed here as articulation qua creation/conquest of a certain historical-specific world. We do not think of the "sociality" which influences the world by exerting external pressure, we think of the fact that capitalism organizes in the world, as the "historical" world does as a result of its principle of reality.

\section{Three answers to the question of why we do not live in the world}

\section{Immanence and coexistence: Divergence of the world and globalization}

A selection of examples is quoted here, in which Jean-Luc Nancy presents the subject of "non-world". We experience the "end of the world" because

“... the world has lost its capacity to 'form a world' (faire monde): it seems only to have gained that capacity of proliferating, to the extent of its means, the 'unworld' [immonde] (...). The fact that the world is destroying itself is not a hypothesis: it is in a sense the fact from which any thinking of the world follows", 30

and

"... there is no longer any world: no longer a mundus, a cosmos, a composed and complete order (from) within which one might find a place, a dwelling, and the elements of an orientation." 31

A significant part of Nancy's philosophy presents his realization of the amalgam of Marx and Heidegger, ${ }^{32}$ and he generates a criticism of the various forms of the "non-world" (immonde ${ }^{33}$ ).

A critical claim is that the world cannot be measured by globalization, or that globalization, which reproduces old addiction and is the insurmountable horizon of modernity, embodies a threat to the "world". It brings Nancy closer to the thinkers who are focused on the permeation between the author of Capital and the author of Being and Time. ${ }^{34}$ This orientation, with the logic of the appropriation of the world, thematises the globalization space as the use of the world and questions the phenomenological intention to discover the world from the other side. There is always a philosophical meaning behind the fact that globalization is promoted as the world nexus which always includes the exclusion matrices. Controlling the "world" explains the structure of power and it is this control that dictates today's perception of the "world". This deforms the old expression urbi et orbi, "everywhere and nowhere". The world is viewed as a subtractive procession bound by calculation and globalization ("glomicity") is viewed as an "agglomeration" or a "conglomerate". This can be interpreted as the bad infinity of the "positivity" of globalization, since this is how the assertions that global agglomeration provides space for the "infinite growth of techno-sciences" should be understood - they "impair various inequalities, economical, biological, cultural". Globalization is a broken unity and this is also confirmed by some formulations according to which the world perceives itself as "a grey world of instrumentalism, interests, particularities, separation and pain". 35 The constellation of the globalized "world" as a topos of inclusion and exclusion is understood here from the perspective of privatio, as a situation which implies exclusion from the unity - as an epochal loss.

Heidegger offers variations of the "subject" constellations and treats the world as an object which "dislocates" the subject with respect to the world. The modes of "deworldification" are evoked and they affect individuals. Still, Nancy restrains himself from Heidegger's "heroic" gestures. He wants deheroisation - he keeps the distance from the individual who is favoured in a 
heroic loneliness. ${ }^{36}$ Also there are Marx's categories. Nancy recalls from The German Ideology that it is Marx who talks about "world-historical" 37 individuals and who categorically states that proletariat has to be "world-historical" and that its activity has to reach the climax in communism as "world-historical existence". To be more precise, here we are talking about the "existence of individuals" who directly relate to "world history" because there is firm connection between the transformation of history into world history and the paths of (self)emancipation of individuals. Marx mentions the "abundance of real relationships"; thus, Nancy's diagnostic statement about the world indicates the deprivation regarding the "world-historical" situation of individuals.

The French philosopher who is interested ${ }^{38}$ in the category of "individual property" which is neither private nor collective wishes to emphasize that the communist revolution is nothing more than a transfer of the "world nexus" into the mind. ${ }^{39}$ This is why Marx is important; he talks about the world as a "human world" 40 and he unmasks the invariable interpretation of the world, while Nancy, at some points, uses the dual connection between human beings and the world - human being creates the world, but this can occur vice versa, too. This introduced the indeterminacy of the individual's position: the world is indeed her product, but it is also a place where the created thing can turn against her.

To Nancy, the world is "a generalized and continual beginning". ${ }^{41} \mathrm{He}$ refers to the world as the "totality of sense": 42 if it is the world which creates certain

30

Jean-Luc Nancy, The Creation of the World, or Globalization, State University of New York Press, New York 2007, pp. 34-35.

31

Jean-Luc Nancy, The Sense of the World, University of Minnesota Press, Minneapolis 1997, p. 4.

32

Jean-Luc Nancy, A Finite Thinking, Stanford University Press, Stanford 2003.

33

For the term 'non-world' cf. Hannah Arendt, The Human Condition, The University of Chicago Press, Chicago - London 1998, p. 9. 34

Kostas Axelos, Vers la pensée planétaire: Le devenir-pensée du monde et le devenir-monde de la pensée, Éditions de Minuit, Paris 1964; Ce questionnement: approche-éloignement, Les Éditions de Minuit, Paris 2001, p. 40.

35

Jean-Luc Nancy, Hegel: The Restlessness of the Negative, University of Minnesota Press, Minneapolis, 2002, p. 3.

36

Jean-Luc Nancy, "Our World, an interview with Peter Hallward", Angelaki 8 (2/2003), pp. 43-54. doi: https://doi.org/10.1080/0969 $7250320001625 \overline{67}$

37

Udo Tietz, "Die Gesellschaftsauffassung", in: Harald Bluhm (ed.), Deutsche Ideologie,
Akademie Verlag, Berlin 2010, pp. 59-83. On the category wirklichen individuen $\mathrm{cf}$. L. Basso, Marx and Singularity, p. 23.

38

Jean-Luc Nancy, "Communisme, le mot", in Alain Badiou, Slavoj Žižek (eds.), L idée du communisme, Lignes, Paris 2010, pp. 197215, p. 204.

39

The "world nexus" is formed on the basis of the modes of individual property and its corresponding "real relationships".

40

Nancy criticizes Marx for a kind of anthropologisation; this explains Nancy's emphatic questions about the world being human being's product: there is a hypothesis in anthropology about "human being's world" (ibid.). Nancy also makes progress towards "value and world". However, Marx (in Critique of the Gotha Programme) believes that values can have their source in "nature" as well. This is, however, the deanthropologisation of the concept of value.

41

Jean-Luc Nancy, Corpus, A. M. Métailié, Paris 1992, p. 3; Jean-Luc Nancy, La possibilité du monde. Dialogue avec Pierre-Philippe Jandin, Les Dialogues des petits Platons, Paris 2013, p. 33.

42

For the concept of sense in Nancy's work cf. Patrick Roney, "The Outside of Phenomenology: Jean-Luc Nancy on World and Sense", 
connections (the world of A. Schönberg, etc.) then there is always affinity, the "tonality of sense", and a moment of participation. We always consider the participation in the world. That is why the world is not something in front of us to adopt by positioning ourselves as a subject opposed to an object; the world exists only for the one who lives in it. The world is the place of all places, a possibility to acquire place, meta-place, and the topos of habitualisation. It exists only as far as its frames extend; it is coextensive with "its own extension". When Nancy uses the word 'concrete' in the context of the world he evokes "the play between freedom and its communal appropriation" or "individual, singular" property.

Furthermore, the world is a kind of excess with respect to every representation. Here, once more, we come across the paraphrase of the motive which opposes the representative activities of deworldified subject. In the premodernity there is the traditional position of cosmotheoros which observes the world externally. This position is no longer endorsed. Yet a speculative moment is still present because there appeared an activity of representation and ocularcentricity only after this position was articulated. By the means of "world perspective", this activity will deform the world. Capitalism and fascism converge the same way - both "capitalize" the world perspective. Fascism is explicitly said to have been born as a replica due to the disappearance of cosmotheoros.

The world appears in the perspective of "immanence" (mondain) and "coexistence" (mondial). The immanence of the world has a strategic value. We again find ourselves facing Marx's apotheosis, only now he is a thinker who, as a critical interpreter of Feuerbach, defines the meaning of this-worldliness (Diesseits). Has not young Marx so persistently criticized the meanings which questioned "immanence"? We ask the same question as Nancy: was not Marx the one who transposed Welt-Geist into Geist-Welt, clearly emphasizing the world-immanent determinations? That is why Nancy emphasizes that there is nothing beyond this world, there is no "other" world nor eternity embedded in our "space-time patterns". Immanence is the auto-referentiality of the world. Hence the rationality of the possible new epoch is an immanent relation of the world towards itself and Marx's project is a form of self-destruction of the world.

The moment of coexistence takes us to the political philosophy which develops around the "with", the desubstantialised "community". Nancy's esoteric political philosophy of community ${ }^{43}$ should be read together with the immanent tendencies in the world-philosophy and indications such as the "immanent causality of the world". Thinking about the world from the aspect of immanence corresponds to the philosophy which also uses anarchic impetuses. The deteleologised world, "radical materialism" with ex nihilo formula, is indeed impossible to reduce to an entrenched belief in metaphysics:

“... this end of the sense of the world, which is the end of the world of sense in which we had all the points of reference we need in order to continue to manage our significations (...). Or, rather, one will deceive or blind oneself by continuing to endow the word end with a determinable sense (annihilation, liquidation), in the name of which one will then carry on disputes deprived not only of rigor, but of all content." ${ }^{44}$

This tendency really demonstrates something unnoticed in the Western understanding of sense. At the same time, the deteleologised world enables a co-presence that is based on authentic pluralism and the non-metaphysical politics of the world. Therefore, in the whole discourse about the loss of the world there will still be a gleam of light, although with an uncertain outcome. 
When Nancy discusses the term of wealth, he draws the conclusion that capital does not acquire the entire signification through commodities. He thematises the impersonal domination of capital, but he does not want to show the development that has become complete, so that he could keep the intransitive possibility of the dynamics of sense with respect to the dominance of capital. By distinguishing between capital and commodity, we notice a possibility according to which capital does not have the source only from commodity, but also from the wealth that precedes it: here, we emphasize the category of the value of the world.

In this sense, we have the reflections about the world that elude the dichotomy between contingency and necessity, which means that the world is neither contingent nor necessary or that it is both contingent and necessary. ${ }^{45}$ In comparison to Heidegger, Nancy elaborates that the world is no longer divine, and it is not even the world anymore but our mutual world that cherishes the ambition of the philosopher to attach the other meaning of authenticity. Based on this attitude, Nancy emphasizes the necessity of the symbolization of the world and the struggle between the West and capital with itself. In the light of immanence, symbolization represents the adoption of symbols in the process in which the world will face the struggle with itself because the world will create the symbols in relation with itself and symbolization will serve to open the door to a smooth circulation of senses. It is the present quasi-common world that is deprived of symbolic places.

The term 'struggle' seems to be an expression of a homeopathic relation - the transformation of similar into similar. However, it remains uncertain what it means. This type of struggle applies to the logic of immanence, but there are some contradictions: the power of capital should be reflected upon, and the same "struggle" is believed to be the result of capital itself, but it is suggested that this phenomenon remains to be assessed. Why should the West or capital struggle with themselves for the purpose of the affirmation of the world if the dynamic of the bad infinity of capital cannot be detached from "glomicity" or even positioned against the world?

\section{The affirmation of the world through radical transformation: Militant allegiance to the world}

If we start discussion about the world from the aspect of regaining sense, then the question is raised about whether we can discuss the non-existence of the world. This is what Alain Badiou criticized Nancy for. ${ }^{46}$ In contrast to "hermeneutics", the "icon" of sense, Badiou offers objective phenomenology based on the logic of appearance. This is why he names the world a "contin-

South African Journal of Philosophy 32 (4/2013), pp. 339-347. doi: https://doi.org/1 $0.1080 / 02580136.2013 .867398$. Nancy often identifies sense with value, for this cf. JeanLuc Nancy, "The Insufficiency of 'Values' and the Necessity of "Sense", Journal for Cultural Research 9 (4/2005), pp. 437-441. doi: https://doi.org/10.1080/1479758050025 2621.

43

On the ontologisation of communality cf. Jean-Luc Nancy, La communauté désœuvré, Détroits, Paris 2004, p. 68.
44

J. Nancy, The Creation of the World, or Globalization, p. 5 .

45

Ibid., p. 41.

46

Alain Badiou, "Images du temps présent", available at: http://www.entretemps.asso.fr/ Badiou/01-02.3.htm (accessed on November 17, 2015). 
gent disposition" of the being which is "here", the being which is "there", "the place" where being is localized. ${ }^{47}$ Unlike Nancy (with speculative competency but militant political philosophy which disqualifies reality), Badiou describes the world as contingent.

Badiou is focused on the affirmation of the world as well as Nancy. The yes in the world plays an important role in his reasoning, which is applied to the ontological articulation of reality. He denies "reality" in order to affirm the world. Affirmation, as a genuine philosophical act, is of significant importance for his mathematized ontology ${ }^{48}$ and it does not raise any doubt about the absence of the world, but it implies that we live in a world which is not the world. It is an "absence of the world", a "world without the world" or the global market as "the name for the world".

Badiou is closely related to Henry because the constituents of his thoughts are non-relation, the denial of subject-object form and fragmentation, which means that statements are not made based on the interaction between subjects. ${ }^{49}$ However, similarities end here because "the affirmation of one world" is polemically directed towards the existing capitalism, but for the purpose of creating a new world with modified coordinates of existence. This orientation anticipates the affirmative attitude with the aim of the profound transformation of the world. Its actions, as a way of the rehabilitation of philosophical militantism and the articulation of the prescriptive moments that anticipate orientation in contrast to disorientation, are the expression of "counter-affirmation":

"How are we to be faithful to changing the world within the world itself?"50

Although Badiou discusses about "over-world" (sur-monde), about the "world that is becoming", this intention is quite clear with respect to the "world itself'.

The question concerning the reasons for the present existence that deprives us of the world is answered as follows: the connection between capitalism and democracy, or capitalo-parliamentarism. Instead of lamenting about the fact that the dynamics of capital lessen the chance for democracy, Badiou states that the rapid spread of democracy is really caused by a "constitutional fetish" which deprives us of the world. ${ }^{51} \mathrm{He}$ is not interested in different definitions of democracy (democracy is a form of state and not a category of philosophy), ${ }^{52}$ the tensions in the context of democracy, and this is why his relentless negative assessment is still present. However, we still find it important that "democratic emblem", i.e. democratic representation, is actually connected to the world. Based on democracy aimed at the pacification of the world market order, the existing is presented as a "demo-world". Democracy, driven by the world-transnational trends, is isomorphic to "mondialisation", the influences of the mondialised market are spread roughly to every part of the planet. The connection between the French philosopher and Plato ${ }^{53}$ is completely evident. We can use Plato to defame democracy as a field of equivalence of all things. It distributes things that are brought into the context of equivalence in which things resist qualitative differences. However, this (profit + consensus) is an obstacle for creation of the world.

When Badiou completes his attack on democracy, he also raises Plato's question about youth, that is, about a "democratic man" who, not being able to discover the truth, confuses desire with pleasure and is incorporated into the youth. Democracy is then understood as a framework in which there is an endless circulation of opinions and objects in the context of the equivalence 
fetish. Actually, we should mention that in the perspective of equivalence there is always an analogy between the circulation of the object and the circulation of opinion. ${ }^{54}$ By mentioning "youth as the norm of vitality" in today's society, Badiou indicates that the world is accepted only by youth and either correlates youth with the absence of the world or relates nihilism ${ }^{55}$ to animal humanism. Thus Badiou composes a tune that some conservatives also play. Certainly, the French philosopher yearns for "proletarian aristocracy" and "aristocratic transmission". ${ }^{56} \mathrm{He}$ bears in mind "aristocratic communism" and "Platonic communism" which, in comparison to democracy, imposes the non-transitive truth as an indefinite exception, as the "affirmation of universality". ${ }^{77}$ Thus, starting from the Idea, Badiou "represents the world" as Plato himself did. ${ }^{58}$ New meaning is assigned to the quoted notion "in the world itself"; that which is called truth exists in the world but only as an exception. This is called the "immanent exception"59 and it is a breakthrough of transcendence from immanence.

Badiou is not preoccupied with the phenomenological description of the world in meticulous detail. His discourse is about the axioms that demon-

47

"World" is determined by ontology and logic; see Alain Badiou, "Mondes et relations", in: Logiques des mondes, Seuil, Paris 2006, p. 319. David Rabouin, "Objet, relation, transcendental. Une introduction au formalisme de Logiques des mondes", in: David Rabouin, Oliver Feltham, Lissa Lincoln (eds.), Autour de Logiques des mondes d'Alain Badiou, Éditions des Archives Contemporaines, Paris 2011, pp. 23-49.

48

Benjamin Noys, The Persistence of the Negative Edinburgh University Press, Edinburgh 2010 , pp. 134-153, doi: https://doi.org/10.3366/ edinburgh/97807̄48638635.001.0001. Alain Badiou, Second manifeste pour la philosophie, Fayard, Paris 2009, p. 136; Alain Badiou, "Wir müssen das affirmative Begehren hüten", in: Frank Ruda, Jan Völker (eds.), Dritter Entwurf eines Manifest für den Affirmationismus, Merve, Berlin 2008, pp. 45-46.

49

Alain Badiou, Abrégé de métapolitique, Seuil, Paris 1998, pp. 77-89; Peter Hallward, Badiou: A Subject to Truth, Minnesota University Press, Minneapolis 2003, pp. 284. Badiou's philosophy, which rejects "reality" and accepts opinion as a separation, can be understood as a gnostic orientation; cf. Alberto Toscano, "From the State to the World? Badiou and Anti-Capitalism", Communication \& Cognition 37 (3-4/2004), pp. 199-224.

50

Alain Badiou, The Rebirth of History, Verso, London 2012, p. 67.

51

Alain Badiou, "S'orienter dans la pensée, s'orienter dans l'existence. Séminaire public d'Alain Badiou. II. (2005-2006)", available at http://www.entretemps.asso.fr/Badiou/0506. 2.htm (accessed on November 17, 2015).
52

A. Badiou, Abrégé de métapolitique, p. 92.

53

On Platonism cf. Quentin Meillasoux, "Destinations des corps subjectivés", in: David Rabouin, Oliver Feltham, Lissa Lincoln (eds.), Autour de Logique des mondes d'Alain Badiou, Éditions des Archives Contemporaines, Paris 2011, pp. 13-27, p. 18.

54

Frank Ruda, Jan Völker, "Thèses sur une morale provisoire communiste", in: Alain Badiou, Slavoj Žižek (eds.), L'Idée du communisme 2, Lignes, Paris 2011, pp. 215-237. Circulation of objects and opinions was mentioned by these authors, but they did not mention equivalence.

55

Alain Badiou, Lhypothese communiste, Lignes, Paris 2009, p. 28.

56

Alain Badiou, "The Lesson of Jacques Rancière: knowledge and power after the storm", in: Gabriel Rockhill, Philipp Watts (eds.), Jacques Rancière: History, Politics, Aesthetics, Duke University Press, London - Durham (NC) 2009, p. 38.

57

A. Badiou, Second manifeste pour la philosophie, p. 33.

58

Ibid., p. 119.

59

Alain Badiou, "Épilogue", in: David Rabouin, Oliver Feltham, Lissa Lincoln (eds.), Autour de Logique des mondes d'Alain Badiou, Éditions des Archives Contemporaines, Paris 2011, pp. 183-191. 
strate manifestos. The French philosopher, who purifies his philosophy from the elements of actuality, does not provide us with an analysis that would explain why capitalism emerged as an organization of nature, and this is the reason why his argumentation seems declarative from time to time. A democratic consensus (connected with economy, which is here understood as trade in commodities) seems to Badiou as a springboard for depolitisation at the level of the world and, what is more, he claims that everything shaped by consensual principle is an obstacle to human emancipation. This is why he refuses to allow any maxim of "political ecology" to be incorporated in his philosophy and states that the discourse of ecology is opium of the present. Badiou, a connoisseur of the philosophy of nature ${ }^{60}$ who calls himself a Cartesian, declares that 'ecology' represents a transmission mechanism for depolitisation. ${ }^{61}$ He refuses to affirm the world by using the norm of nature which is beyond the "human" world. However, by rejecting nature as an abstract Spinozistic substance, Badiou goes to extremes by confirming human being's dominance over nature. By neglecting the philosophical orientations which emphasize that a human being can realize himself only if he respects nature, we fail to notice that "capitalism" draws both society and nature into its whirl.

A quasi-world that appears before us is also an atonic world (atonia) ${ }^{62}$ because it laments about the inability to view the world, confirms our cognitive incompetence and immerses us into the abundance of endless communication. We lack the decision that would be focused on truth-exception. Here, Badiou introduces the term 'point' which is formed based on Kierkegaard's articulation of existence as an absolute choice. Worlds described from the perspective of "democratic" inertia are opposed to the choices that are not based on externality. This manifests in the case of the circulation of things and opinions - here, the choice is made by itself. This is the choice that involves all other choices. Here Badiou discusses "subjective truth" and "disjunction without remainder".

Badiou accepts the processes of creative interpretations. We can see the influence of Marx and Engels, who highly value the world-historical effects of capitalism as the way of deteriorating the existing relationships, of disintegration of rigid frameworks. However, in Badiou's case, the destruction which clears the way is seen on the ontological level. Capitalism, which weakened the historically developed particular relationships, is praised. This process takes over the power of the command position of the One, and Badiou, who focused his philosophy on the articulation of multiplicity and revealed the nonexistence of the Whole and affirmed the inconsistency of reality, welcomes all this. Capitalism undermines the dominance of the One and here we have an ontological perspective: capitalism is not only a historical phase in the succession of historical epochs, but it is also an ontological constellation that allows the capital machinery to be analysed from formal-axiomatic aspects. In our interpretation, capitalism with its logic of real abstractions appears as indifferent towards historical specificity since not a single historically developed relationship can resist the "abstract potency" of capital. Here, we can just have a glimpse of the complex relationship between global capital movements and national-particular relationships. Although Badiou is aware of the fact that particular entities are always rearticulated by the abstract-impersonal logic of capital, that is, that there is a certain dialectics between the indifference of capital and its reliance on particular constellations, we still cannot find any deeper articulation of this problem in his work. ${ }^{63}$ 
We only need to point out the "nihilistic potency" of capital that causes absence of the world. Even though capital can deteriorate particular relationships, we are still in the regime of the One and not multiplicity. The author of the Logics of Worlds wishes to use the transcendentals of the world to develop a thesis that there is only one world ${ }^{64}$ According to this statement, the world can be described as a series of identities and differences and an infinite number of differences can be accepted as a logical law. The world is transcendentally the same so that individual existences can be different.

We can find that the world is synonymous with names; the meaning of the world occurs as a registry of names. ${ }^{65}$ According to Badiou, the modern constellation is an interval period in which "the nation is nameless"; it is an epoch of democracy that inaugurates "non-nomination". Nowadays, market and mondialisation are the name for the non-world. Badiou is engaged in the political affirmation of "personal", "real" names. The world attributes "the intensity of existence" to all people, but to some people it attributes "weak, negligible existence". ${ }^{66}$

If we wish to summarize Badiou's tendencies, then we can say that they are presented in the philosophical articulation of the mediation between the world and the change of the world. Here, we also discuss creative affirmation in terms of the identification of the non-existent world. It raises various possibilities because there is always tension between history and ontology ${ }^{67}$ and this tension is reflected in the meanings of the world. In this way, the world, which refers to symbolic associations, meanings and the hermeneutics of finitude, is disassociated from the truth that will be uncovered transhistorically. In one part, we will see a clear negatively formulated statement that introduces the triad of society, historicism and the "world", that is, the "historical world". ${ }^{68}$ The event, which is very important for this philosopher, does not represent a realization of the internal possibilities of a situation, nor is it dependent on the

60

Alain Badiou, “La Nature. Cours d'agrégation d'Alain Badiou (Ens - Ulm 2000-2001)", available at www.entretemps.asso.fr/Badiou/00-01.Nature.htm (accessed on November 17, 2015).

61

Alain Badiou, "Live Badiou: Interview with Alain Badiou, Paris, December 2007", in: Oliver Feltham, Alain Badiou: Live Theory, Continuum, London 2008, pp. 136-140, p. 139.

62

Alain Badiou, "Les mondes atones", in Logique des mondes, Seuil, Paris 2006, p. 442. Žižek uses the term 'atonal world' (In Defence of Lost Causes, Verso, London 2008, p. 11), which is associated with atonal music, and here we discuss 'atonic worlds', which refer to a lack of normal tensions.

63

Alberto Toscano, "From the State to the World? Badiou and Anti-Capitalism", Communication \& Cognition 37 (3-4/2004), pp. 199-224; Guillaume Sibertin-Blanc, Politique et État chez Deleuze et Guattari, PUF, Paris 2013, pp. 174-180.
64

Alain Badiou, The Meaning of Sarkozy, Verso, London 2006, pp. 53-71. 65

A. Badiou, "Images du temps présent". There is also the philosophy of nomination, correlation between the names and subjectivity; cf. Alain Badiou, Conditions, Seuil, Paris 1992, p. 222. On the change in non-nomination $\mathrm{cf}$. Bruno Bosteels, Badiou and Politics, Duke University Press, London - Durham 2011, p. 348 .

66

A. Badiou, Rebirth of History, p. 60. 67

Žižek demonstrates this problem by introducing the example of a state that transforms on the ontological level. Slavoj Žižek, "An Answer to Two Questions", in: Adrian Johnston, Badiou, Žižek, and Political Transformations. The Cadence of Change, Northwestern University Press, Evanston (IL) 2009, pp. 174231 .

68

A. Badiou, Abrégé de métapolitique, p. 52. 
"transcendental laws of the world" ${ }^{69}$ What can we do to classify truth as a constitutive exception in a "hermeneutically" determined world? Those "real names" are part of the "operation of ideas" and names are in direct correlation with the world! How can we develop an approach to this "mediation" between the world and the change of the world? How will the truth become the "world"? ${ }^{70}$ Will it be the truth that is still disassociated from the world or will it be the world in which the truth is the world? When we discuss the "truth on the edge of historical revolution", then the truth is "withdrawn from the world law" ${ }^{71}$ Which relationship between the world and history "rises" and "opens"?

\section{Being-in-the-world through the dispossession of the world}

Where Badiou's philosophy is not articulated by political-economic determinations, Franck Fischbach's analyses ${ }^{72}$ are based on the political and economic reflections. We register thorough analyses of production and consumption, and the analysis of time and space in the dynamic of the self-valorisation of capital for the purpose of demonstrating that even today there is a being-inthe-world, but we exist in the world only through privatization. Dispossession is our mode of existence in the world.

Thus, we can register, for example, the thematisation of disturbing our attitude towards an object. ${ }^{73}$ Fischbach, who studies the different aspects of activity and passivity ${ }^{74}$ emphasizes that the attitude towards an object is no longer driven by needs or desires, but envy. We are no longer in a constellation which could be, with the help of Marx, comprehended by creating new needs. The new situation can certainly be related to the dynamics of desire in capitalism and we can refer to Hegel's philosophy of desire from which we can conclude that desire prevails over consumption. Furthermore, here we can refer to Marx's idea of consumption in terms of destruction and negation: consumption completes production and consumption is presented as Hegel's Aufhebung, as destruction and finalization. ${ }^{75}$ However, not even the creation of desires is sufficient for understanding today's capitalism. The creation of desires is too aleatory in the stochastic world and consumes too much time. The path that takes us to the satisfaction of desires has proven to be too slow. A pulse of envy and its constant arousal reduce the duration of the process with respect to the temporality of investment in the creation of desires. The possibility of transferring from one situation to the other situation, determined by elements of envy, results in envy being determined by not having memories of the object, by constitutive amnesia which does not have "nostalgia" for unreachable object. In the case of economization, which is no longer determined by needs and in which the perception of ephemeral-provisional objects acts as "surfing the surface", the destruction of things precedes consumption. Before being drawn into consumption, the object of envy fades into insignificance due to intensified acceleration. There is a change behind all this: the subject of consumption is embedded and has embodied determination, and there exists the subject of passivity which depends on the external object by the logic of deficiency. The subject of envy is simply the subject of pleasure deprived of having a relationship with the world.

In Heidegger, who is important for the interpretation of the different meanings of habitare, the object becomes the main focus. For the purpose of understanding late-capitalistic acosmism, it is crucial to state that it was a constellation without an authentic object. We should shift our focus from the subject 
(Fischbach differs from Badiou, who attaches importance to the exceptional status of the subject): what is crucial about acosmism is that the modern world is seen as an epoch of "extravagant forms of subjectivity" and "ultra-subjectivity". "Neo-subject", which cannot escape from the pressure that forces it to maximize pleasures and production effects, adjusts its subjective life. It does not have an object outside itself, it just tests how fluid it is. It is in this introspection that the late-capitalistic hyper-subject affirms itself. By being disconnected from the world, it is a subject which is directed at a false object and which does not develop its "hyper-subjectivity" based on the attitude towards external dimensions. It is not seen as the one abandoning itself, but, in autoreferential interiority, it is centred at self-control and self-monitoring for the purpose of gaining pleasure and results. ${ }^{76}$ This way, the "neo-subject", which is determined by the dimensions of envy and self-observation, is located outside the world. It is no longer incorporated in the world as the subject of need and it foregoes the infinity of pleasures, thus leading us to the conclusion that the issues of the subject and world have to be separated. Certainly, Fischbach knows that the term 'being-in-the-world' does not represent an expression of immediacy because we are not imminent in the world. This being appears to be dogmatically assumed for a human being who cares about the world, that is, who does not only care about having the world, but about living in it. This is the reason why the dispossession of the world appears through the prism of the different types of mediation so, here, we do not refer to some genuine, original immediacy.

Marx's interpreter Fischbach and his ideas could be viewed as a continuance of the German thinker who says that the natural being can find herself in objectivity and that "non-objective being is a non-being". Although the above-mentioned idea about privacy evokes $\mathrm{H}$. Arendt, who appears to be the source of the idea that directs our attention towards alienation from the world, as well, Marx is more present here, especially his reflections on "private property" that go beyond mere economism and emphasize the different meanings of dispossession. We can use H. Arendt to re-evoke the moments of communitarian embeddedness in the world. However, Fischbach, who criticizes the

69

A. Badiou, L hypothese communiste, p. 191. Johnston was looking for situations when there is association between the 'situation' and the 'world' and he wrote the following: one world and plurality of situations. A. Johnston, Badiou, Žižek, and Political Transformations, p. 73.

70

Daniel Bensaïd, "Alain Badiou and the Miracle of the Event", in: Peter Hallward (ed.), Think Again: Alain Badiou and the Future of Philosophy, Continuum, London - New York 2004, pp. 94-106. doi: https://doi.org/10.504 0/9781472547743.ch-007.

71

A. Badiou, Rebirth of History, p. 60.

72

Franck Fischbach, L'être et l'acte. Enquête sur les fondements de l'ontologie moderne de l'agir, Vrin, Paris 2002; Franck Fischbach, La production des hommes. Marx avec Spinoza,
PUF, Paris 2005; Franck Fischbach, Sans objet. Capitalisme, subjectivité, aliénation, Vrin, Paris 2009.

73

F. Fischbach, La privation de monde, p. 27.

74

Franck Fischbach, "Activité et négativité chez Marx et Spinoza", Archives de Philosophie 68 (4/2005), pp. 593-610.

75

Artemy Magun, "Marx's Theory of Time and the Present Historical Moment", Rethinking Marxism 22 (1/2010), pp. 90-109. doi: https:// doi.org/10.1080/08935690903411693.

76

Pierre Dardot, Christian Laval, La nouvelle raison du monde. Essai sur la société neolibérale, La Découverte, Paris 2009, p. 433. 
ignorance of social moment ${ }^{77}$ cannot be satisfied with any type of philosophy which is not predominantly critical of society. Certainly, the author of the book The Human Condition gives a lot of valuable information about the world, but she cannot direct the thought expressed here. Fischbach could address the issues of the world from the perspective of the "commons". Today's description of the devastation of the common domain and the privatization of the commons affects the issue of privatization. The world cannot be reconsidered without the commons as a cohesive tissue and the privatization of commons leads to privatization with respect to the world. The dispossession of the world can be fully reflected based on the criticism of the expropriation of the commons. However, Fischbach does not follow this idea even though there is a basis for his thesis that today we live in seclusion from the world. ${ }^{78}$

Here, Heidegger is not mentioned only as a philosopher whose thought can be used to harshly criticize the subject-object relationship, criticize the hypothesis of interiority and discuss the external position of the subject in the world. Based on Heidegger's writings, we can also discuss the capital-driven temporalisation and spatialisation. Let us mention a supportive argument that was based on the analysis of the spaciousness of being-there, from which we could draw the conclusion about the configuration of space which was subjected to the processes of modern metrics and in which the neutralization of locus as the "point of the world" is thematised. This way, we can discuss the modes of encountering things that are situated in a more meaningful whole and we can discuss "orientation" which builds the relationship between things during realization of certain tasks. ${ }^{79}$ Should we not consider the things in space that are similar to existence (Dasein) which is constantly directed to exteriority? Should we not discuss things in the sense that space exists in the co-existential exteriority relation of the things themselves? Is not space an expression of the co-existential objects that summarize social determinations?

Anyhow, Marx's thought is filtered in Fischbach's work: if we wish to form an idea about the historical certainty of acosmism, we have to refer to Marx because his work shows the crucial issue related to temporalisation and spatialisation as historically marked processes ${ }^{80}$ Only on the basis of these certainties can we understand the way the subject on the other side of the world is produced, as well as the world which is reduced to the "external reality which is extended in space". 81

If we wish to highlight the presented tendencies, we can apply the notion (independently of Fischbach) of the historical specifications of all social relationships. This way, we can discuss the historical specification of the world and the dispossession of the world as well. This does not mean that we should abandon the world as a metaphysically invariant structure, but that we should abandon the explanation about the creation of historically determined world from the perspective of capitalism. It should be noted that not even globalization as a synchronization field can be understood as a mere use of planetary space as much as it can be understood as a creation of an environment suitable for capitalism in the context of premodernity. Understood in such way, globalization is an interference with non-capitalist configuration for the purpose of the creation of its own externality.

Fischbach wants to analyse the consequences of converting time into space in regard to the world. However, Marx's idea about the annihilation of space by time is considerably discussed ${ }^{82}$ even though the French philosopher does not attach philosophical importance to this idea, rather a descriptive one. Here, we wish to show Marx's reflexivity that does not end with negating space. It is 
more important to emphasize a contradiction: on the one hand, there is the annihilation of space caused by advances in transport and communication, while on the other hand, there is respatialisation, that is, the affirmation of the new spatial configuration which implies combination of extension and unification of commodity space worldwide. Capital refers to time exclusively through spatialisation. The fact that capital tends to produce goods worldwide and expand its production to the planetary framework is its immanent essence. Even the mentioned sentence from Capital should be understood based the on understanding of space: there exists a collection/accumulation of goods, but always in space. Separation, ${ }^{83}$ which is very important for the dynamics of capital and which is a distinctive characteristic of capital, is always related to capital whose self-valuation is driven by expansion.

This way, we can discuss the time that becomes spatial. It is nothing other than the term which has already been defined by György Lukács (History and Class Consciousness) as a dominance of dead labour over living labour by machines that will subordinate qualitative time to abstract time, thus becoming susceptible to abstract interpretation of space. The measure of duration is spatial measure. This spatialisation of time and colonisation of abstract space, that is, the subordination of qualitative time in the continuity of temporal metrics is supported by superiority of the present over the future. Thus, this dominance of present will prevail and it can even be confirmed by the law of value according to which value can be expressed by the mediation of present. Spatialisation provides explanation for understanding the world in which capital goes beyond its quantitative limits and where there is a connecting arch between the local and the global world.

Non-neutral space, which destroys the qualitative element of time, casts light on the temporality that coincides with itself in an eternal present and in the complete synchronization of planetary space. Capitalism simultaneously combines and recombines the constant flux and demobilization, creative destruction which reaches infinity and stiffness, dynamic and static, historicism and immobilism, progressivism and eternal present. Although he is aware of the particular difficulties in addressing the problems, Fischbach suggests the historisation of time as a counteract to dispossession: a world that would not appear through dispossession would imply the rearticulation of the relation

77

Franck Fischbach, "Comment penser philosophiquement le social ?", Cahiers philosophiques 132 (1/2013), pp. 7-20.

78

Pierre Dardot, Christian Laval, Commun. Essai sur la révolution au XXIe siècle, Éditions La Découverte, Paris 2014.

79

Jeff Malpas, Heidegger's Topology: Being, Place, World, MIT Press, Cambridge (MA) 2006, p. 91

80

David Harvey, Spaces of Capital: Towards a Critical Geography, Routledge, New York 2001, p. 56.

81

The point here is the mondialisation. See F. Fischbach, La privation de monde, p. 60.
82

David Harvey, The Enigma of Capital, Profile Books, London 2010, p. 155; Henry Lefebvre, The Production of Space, Blackwell, Oxford 1991, p. 130.

83

About Marx's ideas about separation cf. Michael Lebowitz, Following Marx: Method, Critique and Crisis, Haymarket, Chicago 2009, p. 346. doi: https://doi.org/10.1163/ ej.9789004149427.i-372. In Fischbach's work, there is a problem about reducing space to a quantitative moment. Can we think about it in a non-traditional way, which implies that space can be understood from the qualitative perspective and time from the quantitative perspective? See F. Jameson, Representing Capital, p. 109. 
between space and time, and saving time by not subjecting it to the imposed space. In this way, human beings become more open to the world and they withdraw from the dominant state of addiction to consumption, that is, from the situation in which fake appropriation of objects is present.

\section{Instead of conclusion: Does the world need to be saved?}

Firstly, the selected examples presented a critical specificity of the modern understanding of the world. Afterwards, we presented three representative replicas of the crisis constellation which gave answers to the question as to why we do not live in today's world. Our interpretation of certain reflections was preceded by the analysis of the movement of real abstractions as an operating principle in capitalism and as something inevitable for the understanding and situatedness of the world. Moreover, Nancy's reflection about the divergence between the world and globalization can be understood in the context of his ontologisation of communality and communism. Badiou's Platonic communism is a persistent reflection of today's non-world and the absence of paths indicating the important link between democratic parliamentarism and capitalism. Through politico-economic reflection, Fischbach engages in production of an insight based on Heidegger and Marx, and proves that withdrawal from the world is a form of existence. We all have the same aim and it is the affirmation of the world, the confirmation of all that represents the world: all of them, at least implicitly, assume subjects who are not deprived of deprivation. ${ }^{84}$ Therefore, the deprivation of the world is experienced as an impetus for the critical understanding of the existing.

Can we think about the idea of saving the world which we, after all, recognized in Marquard's work? Certainly, from Marquard's perspective, we do not bear in mind a conservative category of rescuing, we bear in mind the possibility which is powered by the synthesis of the negative energy of criticism and affirmation of the world. Therefore, is there a possibility of the non-conservative conservation of the world? Although we did not agree with Badiou's Cartesianism, according to which the self-constructed human being dominates over the nature, his alienation from ecology as the last appellate instance cannot be ignored. The different forms which are already widespread in ecology, such as sustainable development, are not what we are looking for here. We should direct our attention towards the consideration of the category of rescuing from the aspect of philosophy. ${ }^{85}$

Nowadays, there is a wide range of references to the enigmatic biblical concept of katechon, to a "restrainer" ${ }^{86}$ We should consider strategically applying this term to the world. The paradox is that, at the same time, it acts against Anti-Christ and against the event which is marked as parousia and could take place after the disaster. Does not katechon represent the meaning of the "delay of the end of the world" in this instance? ${ }^{87}$ Couldn't we consider katechon as an affirmation of the world, but at the same time keep the criticism of the existing as a bearing support?

In Badiou's work, transcendence was extremely explicit, so it is important to consider our suggestion concerning his remarks. For him, a radical change is related to an "event" and it involves the alternation of the existing transcendent regime with respect to the world. Yet some of the interpreters of his work have had difficulties with the lack of information about the pre-event dimensions, and those dimensions indicate the situationality in the world. Katechon implies sensitivity towards the "eventless", "minor", "gradual" political-eco- 
nomic changes: in the end, the consequences of these changes will be meaningful only from the retrospective perspective (this could be interpreted as the acknowledgment of not only the "Event", but also the process). Furthermore, katechon also includes sensitivity towards all the aspects of the destabilized welfare state which are directed towards the protection of the commons as the basis of the world's existence. However, the most important thing is that the "restrainer" affirms a defence against the effects of colonisation by upcoming real abstractions and not just a mere conservation of the existing. In other words, katechon represents a confirmation of all those possibilities that are against the dispossession of the world.

However, if we follow this path, it implies a critical-reflexive "going through" 88 the existing processes of abstraction, a non-natural immersion into the world. It is not an immersion for the purpose of mere conservation, not even for the purpose of the reconciliation with the existing. Paradoxically, no unchanged things in the world can be saved. Therefore, according to Badiou, the world always causes hermeneutics, the interpretation of meanings. We should also discuss critical hermeneutics in real abstractions in the world. This could represent the basis for a critical philosophy of the world.

\title{
Alpar Lošonc
}

\section{Zašto više ne živimo u svijetu?}

\begin{abstract}
Sažetak
Počevši s krizom ukorijenjenosti u svijet kasnog kapitalizma, članak predstavlja reprezentativne replike u vezi s ovakvom, krizom uzrokovanom konstelacijom. Članak naglašava tri odabrana odgovora na pitanje zašto ne živimo u svijetu i zašto smo suočeni s izrazima poput ne-svijet. Jean-Luc Nancy obrazlaže sofisticiranu i visoko spekulativnu filozofiju koja se bavi pridavanjem značenja svijetu: posebnu pozornost posvećuje kraju svijeta putem globalizacijskih procesa. Razvijajući jednu militantnu filozofiju kapitaloparlamentarizma, Alain Badiou naglašava jaz između transcendentalnosti svijeta i uvjeta kasnog kapitalizma. Franck Fischbach se bavi artikulacijom našeg sudjelovanja u svijetu kroz razvlaštenje te nas vodi do značenja privatiziranog svijeta. Ističući značaj analize reprodukcije kasnokapitalističkog društva za značenje svijeta, autor članka nudi argumentaciju temeljenu na reartikulaciji pojma katehon da bi spasio svijet. Pozivajući se na implikacije realnih apstrakcija kao principa realnosti u kapitalizmu, autor nudi kritičku hermeneutiku realnih apstrakcija.
\end{abstract}

\section{Ključne riječi}

svijet, kriza, kapitalizam, realna apstrakcija, društvene odrednice, katehon

84

Günther Anders uses similar formula, but in a different context. See Günther Anders, Die Antiquiertheit des Menschen, C. H. Beck, München 1961.

\section{5}

Cf. Heinrich Kaulen, "Benjamins Begriff der Rettung", in: Michael Opitz, Erdmut Wizisla (eds.): Benjamins Begriffe, 2 Bände, Suhrkamp, Frankfurt a/M 2000, pp. 619-664.

86

Giorgio Agamben, The Time that Remains: A Commentary on the Letter to the Romans, Stanford University Press, Stanford 2000, p. 109; Carl Schmitt, The Nomos of the Earth in the International Public Law of the Jus Publicum Europaeum, Telos Press, New York
2003, p. 60; Paolo Virno, Multitude Between Innovation and Negation, Semiotext(e), Los Angeles 2008, pp. 56-61; Roberto Esposito, Immunitas: The Protection and Negation of Life, Polity, London 2011, pp. 52-79.

87

The same as Virno, but not in terms of the philosophy of the world.

88

B. Noys, The Persistence of the Negative, $\mathrm{p}$. 171. Frederic Jameson, ,Lenin and Revisionism", in: Sebastian Budgen, Stathis Kouvelakis, Slavoj Žižek (eds.), Lenin Reloaded: Towards a Politics of Truth, Duke University Press, Durham (NC) - London 2007, pp. 59-73. doi: https://doi.org/10.1215/9780822389552-005. 


\title{
Alpar Lošonc \\ Warum leben wir nicht mehr in der Welt?
}

\begin{abstract}
Zusammenfassung
Beginnend mit der Krise, die in Zusammenhang mit der Eingebundenheit in die Welt des Spätkapitalismus steht, präsentiert der Artikel repräsentative Nachbildungen in Bezug auf diese krisenbasierte Konstellation. Er betont drei ausgewählte Antworten auf die Frage, warum wir nicht in der Welt leben und warum wir mit Begriffen wie Nicht-Welt konfrontiert werden. JeanLuc Nancy erarbeitet eine verfeinerte und äußerst spekulative Philosophie, die sich mit der Signifikation der Welt befasst: Er legt ein besonderes Augenmerk auf das Ende der Welt durch die Globalisierungsprozesse. Indem er eine militante Philosophie entwickelt, die eine Beziehung zum Kapitalparlamentarismus hat, pointiert Alain Badiou die Kluft zwischen dem Transzendentalen der Welt und den spätkapitalistischen Bedingungen. Franck Fischbach beschäftigt sich mit der Artikulation unserer räuberischen Teilnahme an der Welt und führt uns zu der Bedeutung der privatisierten Welt. Indem er auf die Wichtigkeit der Analyse der Reproduktion der spätkapitalistischen Gesellschaft für die Bedeutung der Welt hinweist, bietet der Autor des Artikels die auf der Neubestimmung des Begriffs Katechon fußende Argumentation, mit dem Ziel, die Welt zu retten. Unter Rückblick auf die Implikationen der realen Abstraktion als Realitätsprinzip im Kapitalismus liefert sie die kritische Hermeneutik der realen Abstraktionen.
\end{abstract}

\section{Schlüsselwörter}

Welt, Krise, Kapitalismus, Gesellschaft, soziale Determination, katechon

\section{Alpar Lošonc \\ Pourquoi ne vivons-nous plus dans le monde?}

\section{Résumé}

Prenant pour point de départ la crise liée à l'enchâssement du capitalisme tardif dans le monde, cet article met en avant les répliques représentatives de la constellation sur laquelle cette crise est basée. Trois réponses privilégiées ont été soulignées répondant à la question de savoir pourquoi ne vivons-nous plus dans le monde et pourquoi ne sommes-nous plus confrontés à des concepts tels que le non-monde. Jean-Luc Nancy a élaboré une philosophie sophistiquée et hautement spéculative ayant trait à la signification du monde et prête une attention particulière à la fin du monde causée par les processus de globalisation. Développant une philosophie militantisme liée au capitalo-parlementarisme, Alain Badiou a souligné le fossé entre le caractère transcendant du monde et les conditions du capitalisme tardif. Franck Fischbach s'est concentré sur la manière dont s'articule notre participation au monde par dépossession et nous conduit à une signification d'un monde privatisé. En mettant l'accent sur l'importance d'une analyse de la reproduction de la société du capitalisme tardif pour la signification du monde, cet article propose une argumentation basée sur une nouvelle articulation de la notion de katechon qui vise à sauver notre monde. Il propose une herméneutique critique des abstractions réelles en se référant aux implications d'une réelle abstraction en tant que principe de réalité.

\section{Mots-clés}

monde, crise, capitalisme, abstraction réelle, déterminations sociales, katechon 